\title{
Correction to: Estimating critical path analysis on digital topology of the connectivity of pore media
}

\author{
Yibo Zhao ${ }^{1,2}$
}

Published online: 17 November 2018

(C) Springer Science+Business Media, LLC, part of Springer Nature 2018

\section{Correction to: Multimedia Tools and Applications (2018) https://doi.org/10.1007/s11042-018-6587-z}

The author regrets that the acknowledgment of the financial support was left out from the original publication. The acknowledgement is written below:

Acknowledgements This work is financially supported by the NSF Grant of China (no. 61572007).

Publisher's Note Springer Nature remains neutral with regard to jurisdictional claims in published maps and institutional affiliations.

The online version of the original article can be found at https://doi.org/10.1007/s11042-018-6587-z

Yibo Zhao

zhaoyb678@163.com

1 School of Mathematical Sciences, University of Electronic Science and Technology of China, Chengdu 611731 Sichuan, China

2 School of Data and Computer Science, Shandong Women's University, Jinan 250300 Shandong, China 